\title{
Thermal Dissipation Effect on Temperature-controlled Friction Stir Welding
}

\author{
Ana Magalhães ${ }^{1}$ (D), Jeroen De Backer ${ }^{1}$, Gunnar Bolmsjö ${ }^{2}$ \\ ${ }^{1}$ University West, Department of Engineering Science, Trollhättan, Sweden. \\ ${ }^{2}$ Linnaeus University, Växjö, Sweden.
}

How to cite: Magalhães A, Backer J, Bolmsjõ G. Thermal dissipation effect on temperature-controlled Friction Stir Welding. Soldagem \& Inspeção. 2019;24:e2428. https://doi.org/10.1590/0104-9224/SI24.28

\begin{abstract}
During Friction Stir Welding (FSW) of complex geometries, the thermal dissipation, induced by geometric features or the surrounding environment, may strongly affect the final weld quality. In order to guarantee a consistent weld quality for different conditions, in-process welding parameter adaptation is needed. This paper studies the effect of thermal dissipation, induced by the backing bar thermal conductivity, on the weld temperature and the temperature controller response to it. A new temperature sensor solution, the Tool-Workpiece Thermocouple (TWT) method, was applied to acquire online temperature measurements during welding. An FSW-robot equipped with temperature control, achieved by rotation speed adaptation, was used. AA7075-T6 lap joints were performed with and without temperature control. The cooling rate during welding was register plus macrographs and tensile tests were assessed. The controller demonstrated a fast response promoting the heat input necessary to maintain the set welding temperature. The results demonstrated that temperature control using the TWT method is suitable to achieve higher joint performance and provides a fast setup of optimal parameters for different environments.
\end{abstract}

Key-words: Friction stir welding; Cooling rate; TWT method; Temperature control; Aluminium alloy.

\section{Efeito da Dissipação Térmica Inducida Durante Soldadura por Friçcão Linear Sob Controlo de Temperatura}

Resumo: Durante a Soldagem por Friç̧ão linear (FSW) de geometrias complexas, a dissipação térmica, induzida por características geométricas ou pelo ambiente circundante, desempenha um papel importante na qualidade final da junta. Para garantir uma qualidade consistente em condições diferentes é necessário a adaptacão de parâmetros durante o processo. Este artigo estuda o efeito da dissipação térmica, induzida pela condutividade térmica do material da barra de suporte, na temperatura da soldadura e na resposta do controlador de temperatura a esta. Um novo método para adquirir temperatura, Tool-Workpiece Thermocouple (TWT), foi aplicado para a aquisição de medições de temperatura online durante a soldadura. Um robô-FSW equipado com controle de temperatura, obtido pela adaptação da velocidade de rotação, foi usado. Foram producidas soldaduras de juntas sobrepostas de AA7075-T6 com e sem controle de temperatura. A taxa de arrefecimento durante a soldagem foi registrada, assim como macrografias e testes de tração foram analisados. O controlador demonstrou uma resposta rápida promovendo o aquecimento necessária para manter a temperatura de soldadura selecionada. Os resultados mostram que o controle de temperatura usando o método TWT é adequado para alcançar juntas com melhor desempenho e fornece uma selecção rápida de parâmetros ideais para diferentes ambientes.

Palavras-chave: Soldadura por fricção linear; Taxa de arrefecimento; Método TWT; Controle de temperatura; Ligas de alumínio.

\section{Introduction}

Automotive and aeronautic industries have demonstrated a high interest in the use of aluminum alloys due to their low weight-strength relation. However, some aluminum alloys cannot be welded using traditional fusion welding methods. Friction stir welding (FSW) provides an opportunity for the implementation of these alloys in such fields.

FSW is a solid-state welding process that gives the possibility to join non-weldable aluminum alloys, such as 2000 and 7000 aluminum series. This welding process occurs in a solid-state and is based on a thermo-mechanic principle. A tool, consisting of a probe and a shoulder (see Figure 1), is pressed under rotation onto the workpiece material to be welded, corresponding to the plunge and dwell process stages, and then traversed along the joint line. A complex material mixing, promoted by frictional heat and plastic deformation, provides then the materials joining. The main welding parameters in this process are the tool design, the rotational speed, welding speed, and the axial force, see Figure 1. 

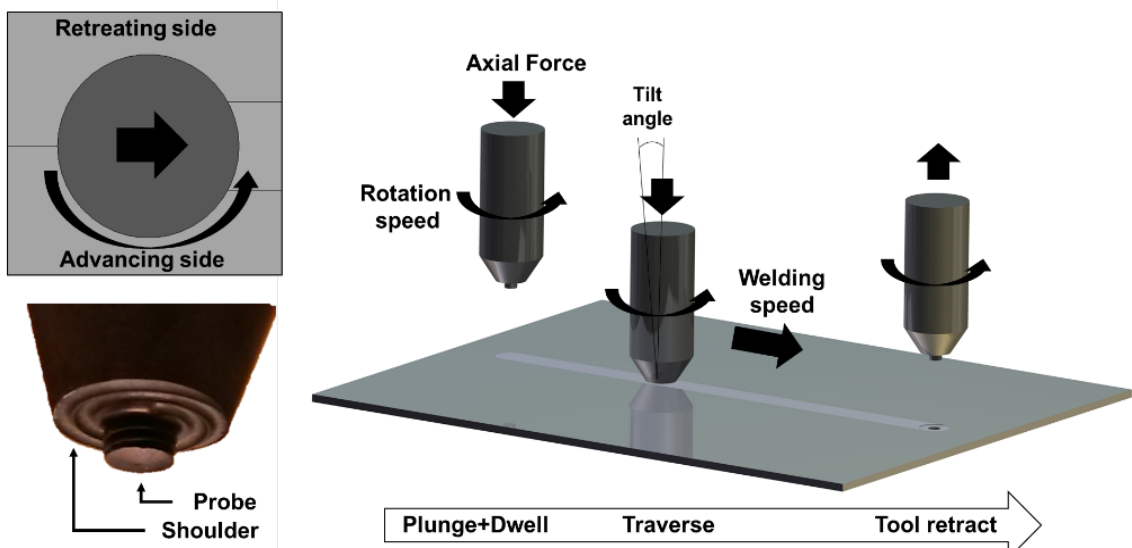

Figure 1. Schematic representation of the friction stir welding process with reference to the different welding stages, its main welding parameters, the tool geometry used during the experiments and the peculiarity of advancing and retreating side.

Typical FSW operations are straight joint lines using constant weld parameters, resulting in a stable process with consistent weld quality. In the case of complex geometric components, the surrounding environment plays an important role in the final weld quality, especially in thermal aspects. The cooling rate imposed during welding, mainly by geometric factors, affects the peak temperature, thus the final joint microstructure and, as a consequence, the mechanical properties, and weld performance.

The decrease of the welding temperature peak and the increase of the cooling rate by submerging the workpiece in water during welding have been proven to improve substantially the joint mechanical properties [1,2]. Submersed FSW however, present limitations on complex components due to the numerous challenges that arise welding underwater. The use of backing bars with higher thermal conductivity, such as of copper material, has been reported to present also improvements to the joint quality.

Zhang et al. [1], demonstrated that the backing bar material plays an important role in the weld temperature by comparing copper, carbon steel and graphite used as backing bar materials. Better results were reported to be achieved with the steel backing bar material and void formation was observed when a copper backing bar was used [1]. Santos et al. [2], studied the backing bar effect on heat distribution for two different aluminum alloys and backing bars of copper, steel and ceramic were used. The use of a backing bar material with lower thermal conductivity (ceramic) led to lower temperature dissipation during welding, thus achieving higher welding temperatures. Microstructure degradation, and consequently, lower mechanical properties was reported for such welding conditions. In Santos et al. [2] was also stated that not only the welding parameters and the backing plate's thermal conductivity affect the heat transfer condition during welding but, also the workpiece material due to their typical deformation mechanism. The influence of the backing plate's thermal conductivity on the welding temperature was studied by Zhang et al. [3], using numerical analysis. Four different heat transfer coefficients represented the use of different backing bars. It was stated that the use of high thermal conductivity backing bar material may lead to a lower peak temperature, higher cooling rate and narrow weld zone width [3].

The backing bar, which is normally made out of steel, contributes significantly to the heat loss during welding. The use of backing bar materials with different thermal conductivity, affects the heat transfer, the cooling rates, and thus, the welding temperature [2]. With a thermal conductivity decrease of such structural material, higher welding temperatures are reached and the material suffers lower cooling rates [1]. Microstructural changes or even welding defects, such as voids, which can affect the joint performance, can occur depending on the temperature reached during welding [2]. However, with the use of a good parameters setup, high-quality welds can be reached.

Strong thermal disturbances induced along the weld length, by the component geometry or other environmental sources, may affect the weld quality. This welding condition makes the definition of proper parameters a challenging task. The adaptation of welding parameters during welding, to accommodate such disturbances, can provide weld quality consistency throughout the whole weld. The selection of optimal parameters demands the execution of several weld trials, being time-consuming and costly. Online temperature control methods have been proven to achieve good and fast results by some researchers, such as De Backer et al. [4,5], Fehrenbacher et al. [6], Schmale et al. [7] and Ross [8,9].

The acquisition of online temperature measurements during the FSW process with fast and accurate data is required to feedback control of the process. Some temperature measurement methods have been developed and tested for FSW. A method successfully implemented for temperature measurements is the use of a thermocouple embedded in the welding tool. This method can achieve accurate and fast readings, however, requires a predrilled hole and exists the possibility of thermocouple failure during the process [10-12]. Other methods, for instance, infrared camera or thermocouples placed on the workpiece cannot register temperatures closer to the welding temperature peak. In addition, the use of thermocouples in the workpiece provides data only relative to one location and its implementation may damage the component. 
De Backer et al. [4,5], presented an online temperature control system based on temperature measurements by a thermoelectric effect, called tool-workpiece thermocouple (TWT) method, which is also applied in the present work. TWT measurements are achieved by the voltage difference created between the steel of the tool and the aluminum of the workpiece, which relates to the welding temperature from the tool and workpiece interface, see Figure 2 . This method has been proved to provide accurate and fast temperature measurements, being suitable for feedback control application [5,13]. More details relative to temperature measurements for feedback control during the friction stir welding process may be found in Silva et al. [14].

The temperature control approach is based on the heat input control in order to maintain a stable welding temperature during the weld. Several parameters of the FSW process can be controlled during welding, i.e.: rotation speed, welding speed, and axial force. However, the main heat source from the process is considered to be the shoulder area under friction with the workpiece material surface, due to the large area under pressure, the rotational speed is considered an important parameter on heat generation [2,15]. The rotation speed has been proposed by several researchers as the controllable parameter, where the controller makes rotational speed adaptations during welding in order to maintain constant the temperature value pre-selected [4].

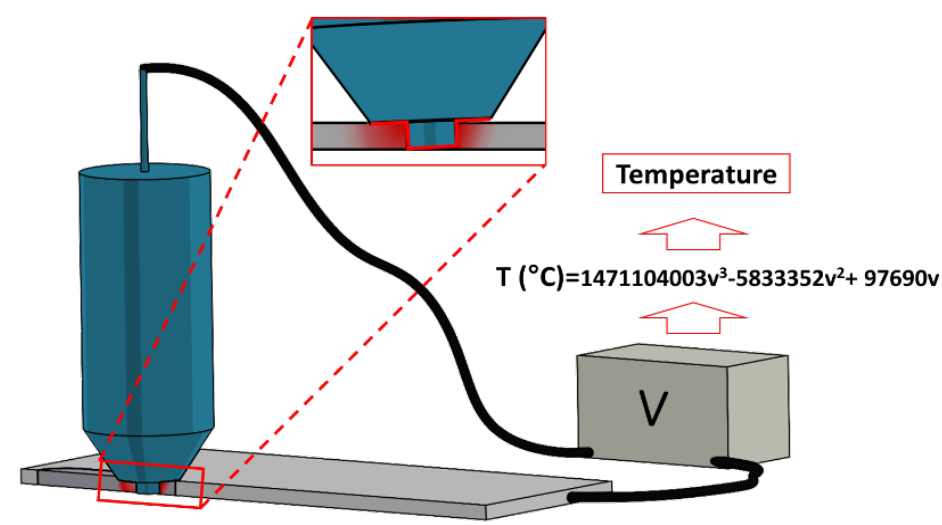

Figure 2. Tool-workpiece thermocouple (TWT) method schematics with the calibration equation to AA7075-QRO90.

The present work is a study on temperature control during the FSW process under different heat loss environments. Series of welds with and without temperature control was performed using backing bar materials with different thermal conductivities. The backing bar thermal conductivity effects on the cooling rate of the welded material was verified by local temperature measurements. Tensile tests and metallographic analyses were performed to verify the weld quality, as well as, study its relation with the temperature and cooling rate reached during welding. The work aims to test the controller in different conditions in order to verify its performance to maintain the temperature and its effects on the mechanical properties.

\section{Materials and Methods}

$2 \mathrm{~mm}$ thick AA7075 aluminum alloy plates, with $250 \times 100 \mathrm{~mm}$, were welded perpendicular to the rolling direction, in a lap joint configuration. The welds were $200 \mathrm{~mm}$ long and the plates were $25 \mathrm{~mm}$ long overlapped. A tool with a $12 \mathrm{~mm}$ diameter scrolled shoulder, a scrolled probe with $5 \mathrm{~mm}$ diameter and $2.8 \mathrm{~mm}$ probe length was used, see Figure 1.

Different backing bar materials were used to induce different cooling rates during welding: stainless steel (SS), nickel (Ni) and copper $(\mathrm{Cu})$. Welds with and without temperature control were performed to verify the temperature controller capacity to maintain the temperature during welding under the different thermal conditions imposed by using the different backing bar materials.

The welding speed was maintained constant at $5 \mathrm{~mm} / \mathrm{s}$ for both cases since this parameter also affects the cooling rate impose during welding. The axial force of $7000 \mathrm{~N}$ and a tool tilt angle of $1^{\circ}$ were kept constant to all welding experiments. The rotation speed, during the uncontrolled welds, referred in work as "Unc" samples, was kept constant at 1100 rpm. At the temperature-controlled welds, the welding temperature was programmed to be constant at $520^{\circ} \mathrm{C}$, such welds are referred to as "TWT". In all welds during the plunging stage, $1050 \mathrm{rpm}$ and $7000 \mathrm{~N}$ were used and temperature of $460{ }^{\circ} \mathrm{C}$ was used as a trigger to initiate the traverse stage, not requiring a dwell time. More details on this welding initialization approach may be found in [16]. The parameters selection was made based on previous welding trials and team members experience.

The tool-workpiece thermocouple (TWT) method was implemented to acquired temperature data online and used as the controllable variable. The TWT method requires the use of a slip-ring to assuring a stable data transition from the rotational condition, which the tool is under, to a static condition. The voltage data is then acquired by using a National instruments model 
and converted to temperature by a LabVIEW software developed for the purpose. The calibration to the tool-workpiece materials combination in order to achieve accurate measurements is presented in Figure 2. More details regarding the calibration of the TWT method may be found in Silva et al. [17] and Magalhães [18].

The cooling rate for each weld was registered by using thermocouples implemented in the workpiece material aiming to verify the thermal influence of the backing bar material on the welding temperature. Type $\mathrm{K}$ thermocouples with wires of $0.5 \mathrm{~mm}$ diameter were used for local temperature measurements. Channels with a width of $2 \mathrm{~mm}$ and $1 \mathrm{~mm}$ deep were created transversal to the weld, at the middle of the weld length, to place the thermocouple wires between both plates. The thermocouples were located on the retreating side, which is typically referred to as the hotter side in FSW process [19].

An ESAB Rosio ${ }^{\mathrm{TM}}$ robot located at the Production Technology Centre in Trollhättan, Sweden equipped with temperature and force feedback control was used to perform the welding experiments. ABB RobotStudio and a LabVIEW-based ContRoStir software were used to control the system. A PID control is used to temperature control, where TWT measurements, the input, is the controllable parameter and the rotational speed, the output, is the controlled parameter. More details related to the welding system may be found in De Backer [13]. Rotational speed limits of 800 to 1500 rpm were selected for equipment safety, avoid damage to the welding tool, backing bar or welding equipment. The TWT temperature, rotation speed, and axial force data were registered per weld.

A basic assessment of the joint performance was made including tensile tests and macrograph examination. Three tensile samples with $12.5 \mathrm{~mm}$ width and $50 \mathrm{~mm}$ gauge length were produced, following the ASTM E8/E8M-09 standard [20], were tested at $1 \mathrm{~mm} / \mathrm{min}$ using a standard Zwick/Roell testing system. Macrographs transversal to the weld were taken in order to identify possible defects developed during welding, such as voids and hook. The samples were etched with Keller's solution.

\section{Results and Discussion}

\subsection{Temperature measurements}

The temperature data registered by the thermocouples implemented in the workpiece and by the TWT method during a weld are presented in Figure 3. The maximum temperature measured by the thermocouples was approximately $30{ }^{\circ} \mathrm{C}$ lower than the one registered by the TWT method. This difference is mainly due to the intensive plastic deformation at this area which difficult the measurements inside the stirred zone using the thermocouples implemented at the workpiece. As the tool passes by the thermocouples, they have moved away or shortened due to the high forces and stresses involved in the FSW process. For this reason, it is assumed that the measurement point is located at the interface between the heat-affected zone (HAZ) and the thermo-mechanically affected zone (TMAZ), approximately $3 \mathrm{~mm}$ from the weld center. The used of thermocouples in the workpiece only provides in-situ measurements and thereby is not possible to be used for feedback control. Nevertheless, they provide data on the cooling rate sensed by the material after welding.

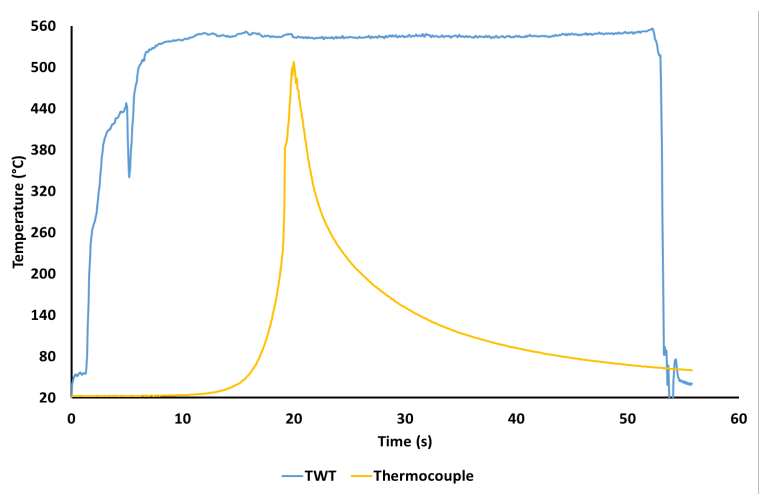

Figure 3. Temperatures registered by using the TWT method and thermocouples during the SS_Unc weld.

\subsection{Cooling rate imposed by different backing bars}

The cooling rates of the different welds obtained from the thermocouples implemented in the workpiece are present in Figure 4. The cooling rates, calculated between $450{ }^{\circ} \mathrm{C}$ and $100{ }^{\circ} \mathrm{C}$, were $37-41^{\circ} \mathrm{C} / \mathrm{s}, 24-29{ }^{\circ} \mathrm{C} / \mathrm{s}, 19-21^{\circ} \mathrm{C} / \mathrm{s}$ for the welds with the backing bar in copper, nickel, and stainless steel backing bars, respectively. As expected, due to the high thermal conductivity from the copper material, the heat loss during the weld is faster reaching approximately the double cooling rate than in welds performed with others backing bar materials. The material with lower thermal conductivity, stainless steel, induced the lowest cooling rate within the backing bar materials tested. This data, thus confirms the thermal influence imposed by the backing bar material in the welding temperature. 


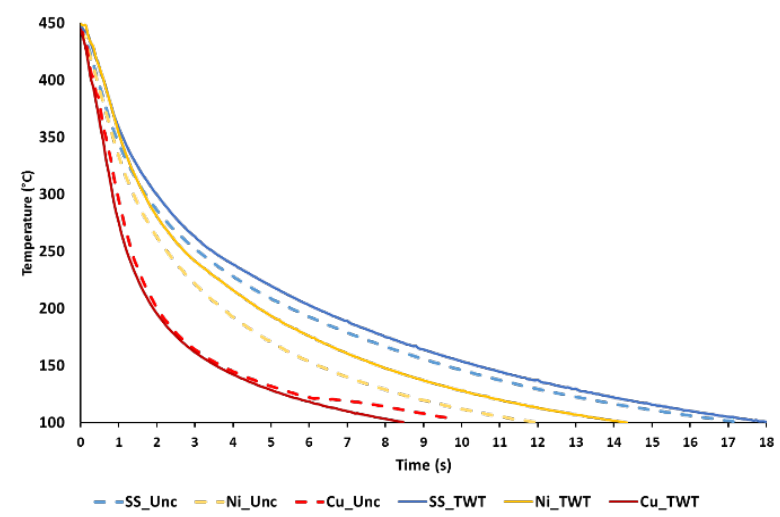

Figure 4. Cooling rate from $450-100^{\circ} \mathrm{C}$ acquired by the thermocouples.

\subsection{Welding temperature}

The TWT temperature data registered during welding for the uncontrolled and controlled welds is presented in Figure 5. As expected, the temperature during the uncontrolled welds is affected by the cooling rate. Higher welding temperature was achieved in welds performed with stainless steel used as backing bar material and lower welding temperature when a copper bar was used. The TWT welding temperature difference between the controller and uncontrolled welds are more evident when the stainless steel backing bar was used $\left(22^{\circ} \mathrm{C}\right)$ than with the nickel backing bar $\left(11^{\circ} \mathrm{C}\right)$.

During the temperature-controlled welds, the temperature was maintained at a pre-selected temperature of $520{ }^{\circ} \mathrm{C}$ by adapting the rotational speed. However, copper as the backing bar was an exception, where the desired weld temperature was not achieved, stabilizing at $480^{\circ} \mathrm{C}$. The rotational speed was set automatically by the controller, reaching its safety limits, at $1500 \mathrm{rpm}$, but this was not enough to build up enough heat, not achieving the desired temperature.

The plunge stage was also affected by the thermal backing material conductivity, see Figure 5 . The plunge-weld transition was set to initiate by reaching a pre-selected temperature $\left(460^{\circ} \mathrm{C}\right)$, however, with the fast heat dispersion occurring when a copper backing bar is used, the time to build up the expected temperature was higher. A delay of approximately $5 \mathrm{~s}$ was verified during the plunge stage of the weld performed with the copper backing bar when compared with the welds using the steel or nickel backing bars.

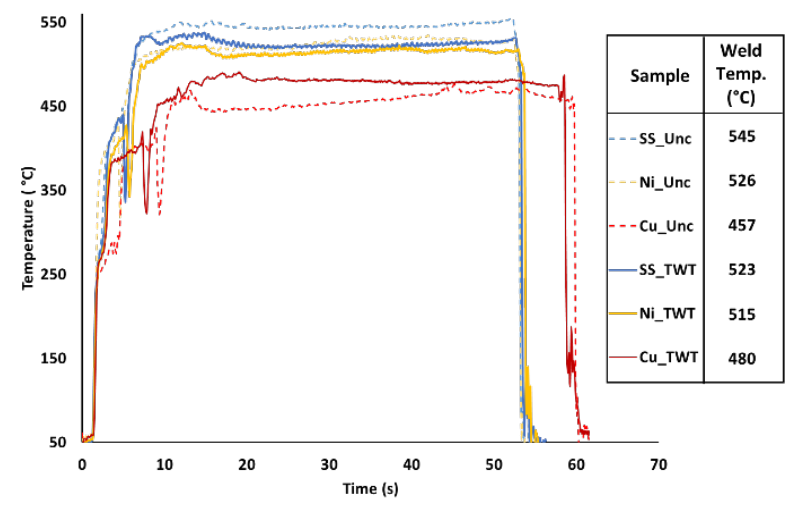

Figure 5. Temperature data registered during welding and the average value from the traverse welding stage for the controlled and non-controlled welds.

\subsection{Axial force and rotational speed output}

The axial force and rotation speed data registered are presented in Figures 6 and 7, respectively. In all welds, uncontrolled or controlled, the axial force was constant at $7000 \mathrm{~N}$, as programmed (Figure 6). The rotation speed, during the uncontrolled welds, was also maintained constant at $1100 \mathrm{rpm}$. For the temperature-controlled welds, the rotation speed was adjusted automatically by the controller depending on the heat input needs for each setup (Figure 7). 


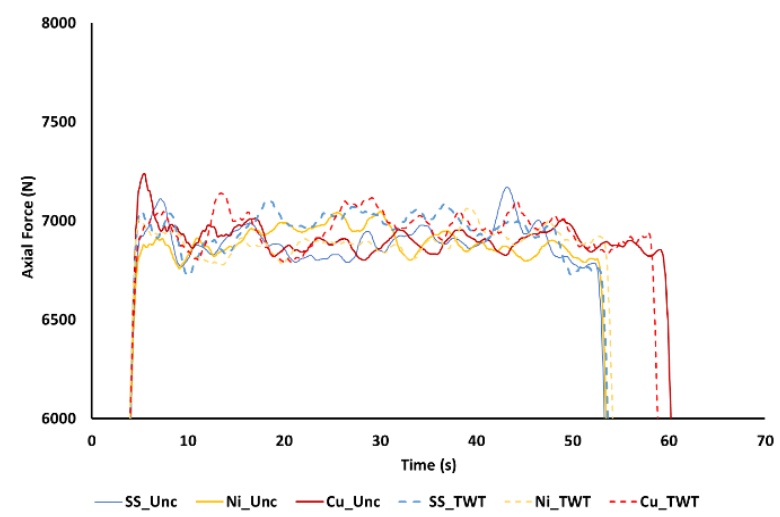

Figure 6. Axial force data registered during the welds.

The welds under temperature control using the stainless steel backing bar required a rotation speed of approximately $800 \mathrm{rpm}$ to maintain the desired welding temperature of $520^{\circ} \mathrm{C}$, a considerable decrease when compared to the uncontrolled weld with the same backing bar material. This value touched the safety limit set for welding, however, offered enough decrease in heat input to guarantee the desired welding temperature. Concerning the controlled weld performed with the nickel backing bar, the rotation speed stabilized at $1050 \mathrm{rpm}$, achieving the desired temperature. The welding temperature during the uncontrolled weld with the nickel backing bar was not very different from the desired welding temperature set for the control, therefor the rotational speed had not a large variation.

As, mentioned previously, the weld with temperature control using the copper backing bar, did not reach the desired welding temperature $\left(520^{\circ} \mathrm{C}\right)$ due to the rotation speed safety limited pre-set, see Figures 5 and 7 . The rotational speed increased until $1500 \mathrm{rpm}$, the upper limit, and kept at this value during the whole weld length.

In cases when the rotation speed achieves the limit, such as the copper and stainless steel backing bar welds, the controller will no longer respond to other environmental heat loss or heat build-up imposed during welding, limiting the welding system. Extra parameters variations are required in order to maintain the weld temperature, such as changes in axial force or welding speed. The rotational speed limits can also be updated to allow a larger rotational speed variation.

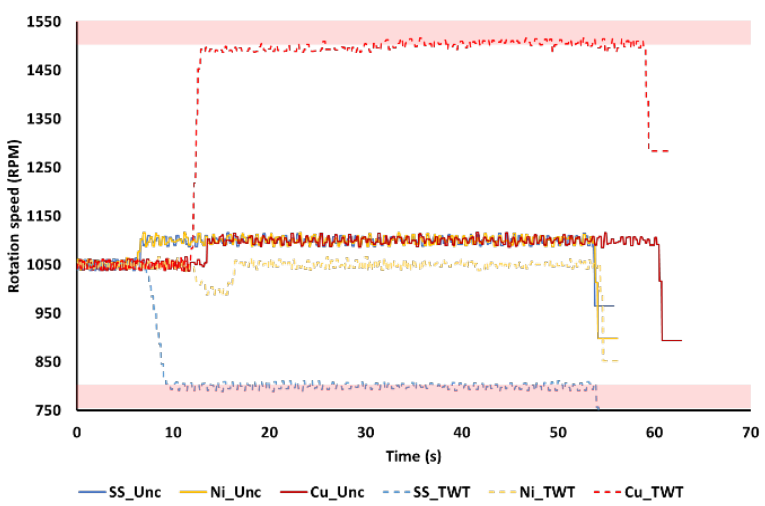

Figure 7. Rotational speed data registered during the welds, uncontrolled (Unc) and controlled (TWT). The safety rotational speed limits of 800-1500RPM pre-selected are represented by the coloured area.

The results had demonstrated that the system has an adequate response to the thermal variations imposed by the backing bar material thermal conductivity, as well as, been able to maintain the temperature stable at the desired temperature during the whole weld within some limitations. Further developments on the controller are necessary to guarantee larger applicability, such as the rotational speed safety limit enlargement.

\subsection{Welds performance assessment}

Tensile tests were performed in order to verify the weld performance. The maximal force achieved during the test, as well as, the mean value of the welding temperature registered to each condition are presented in Figure 8 . All the tensile samples had fracture interface HAZ-TMAZ at the advancing side. 


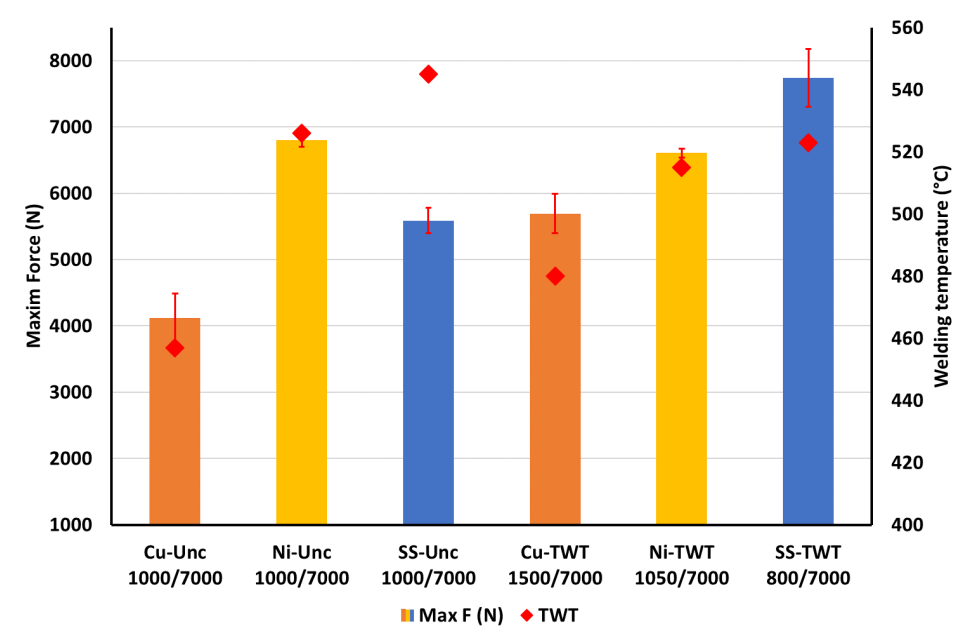

Figure 8. Tensile maximum force average for each weld achieved during tensile tests.

The welds performed with the stainless steel backing bar demonstrated $28 \%$ performance improvement when compared controlled and uncontrolled welds. Regarding the welds performed with the nickel backing bar, a similar result for both, uncontrolled and controlled, was observed. The welding parameters in both cases where very similar and therefore was not expected a variation on its performance. In the case of the welds performed with the copper backing bar, an improvement of $27 \%$ was verified for the welds performed under temperature-control.

The tensile teste results from welds using a copper backing bar are found to be the worst performance compared with the remaining welds. These results reflect the lower temperatures reached during these welds, as reported. Demonstrating the welding temperature influence in the welding quality.
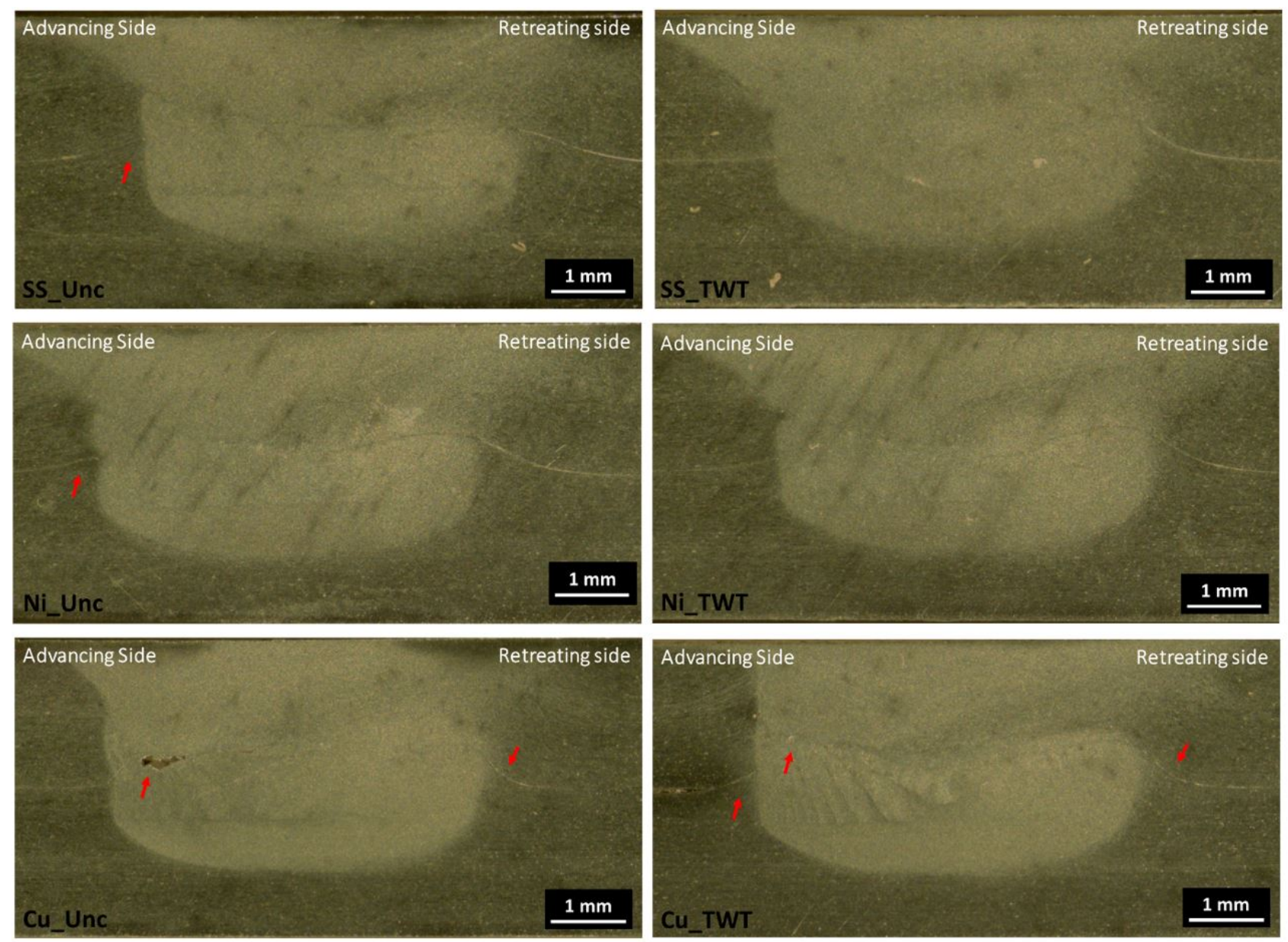

Figure 9. Weld macrographs images from all the welds performed and an indication of defects observed. 
The weld macrographs indicated the presence of weld defects, such as hooking defect and voids, see Figure 9. Hooking defects were consistent in all welds presenting higher angle at the retreating side. The hooking curvature at the advancing side increases with the decrease of thermal conductivity of the backing bar materials, see SS-Unc, Ni, Unc and Cu_Unc in Figure 9. The use of temperature control in the case of the welds performed with the stainless steel backing bar leads to a significant decrease of the curvature. However, the opposite is verified when a copper backing is used, which may implicate the high rotational speed used during this weld.

Voids were observed in welds performed with the copper backing bar, at the advancing side. However, the voids found at the uncontrolled weld were significantly larger than the ones found on the temperature-controlled weld. This is believed to be related to the lower temperature registered during this welds, which is insufficient to perform a proper material mixing, thus leading to the development of this defect. This observation supports the lower performance reached during the tensile tests by the weld performed with the copper backing bar.

The results demonstrate that the temperature controller, using the TWT method, is a suitable method to control the process and to achieve improved weld-quality. In addition, the use of an inappropriate welding temperature leads to a decrease in the final joint performance. It is well understood that high temperature during welding results in microstructure modifications, reducing the mechanical properties. Likewise, the use of lower welding temperature results in insufficient material softening to allow material mixing, which is also related to defects development, such as voids [1,2]. It is thereby required further studies concerning the effect of the welding temperature on the joint performance in order to determinate a range of welding temperature that allows achieving better joint performance.

\section{Conclusions}

This work aims to study the temperature controller performance to maintain the temperature during friction stir welding with different thermal dissipation conditions and the effect on the weld-quality. The different thermal conditions were reached by using backing bar material with different thermal conductivity.

The backing bar material had a strong influence on the cooling rate. The material with higher thermal conductivity (copper) induced a faster cooling rate when compared with a material with lower thermal conductive (stainless steel). Accordingly, the welding temperature, during the uncontrolled welds, was strongly influenced by the backing bar thermal conductivity, achieving higher welding temperature when the material with lower thermal conductivity was used.

Temperature control, using the TWT method, was verified to be a suitable approach to maintain the welding temperature in the presence of different thermal conditions, as well as, to achieve weld-quality improvement. A weld performance improvement of approximately $28 \%$ was reached by using the temperature controller.

This welding approach enables parameter optimization in a quick and accurate manner. It can be especially suited when limited welding conditions information is available or when the components to be welded are subjected to thermal condition variations along the weld path. Further developments are required relative to the controller operational limits, in order to allow large rotational speed variation and, consequently, enlarge its applicability to more challenging thermal disturbances.

\section{Acknowledgements}

The work was made possible through funding of the project MAPLAB from European regional fund (Tillväxtverket, No. 20200328) and Västra Götalandsregionen (No RUN 612-0254-15).

\section{References}

[1] Zhang Z, Li W, Shen J, Chao YJ, Li J, Ma Y-E. Effect of backplate diffusivity on microstructure and mechanical properties of friction stir welded joints. Materials \& Design. 2013;50:551-557. http://dx.doi.org/10.1016/j.matdes.2013.03.034.

[2] Santos JF, Alcântara NG, Rosales MJC. Influência do material do backing no fluxo de calor e na formação de zonas deformadas pelo processo FSW em ligas de alumínio. Tecnologica em Metalurgia, Materiais e Mineração. 2009;5(3):167-172. http://dx.doi.org/10.4322/tmm.00503008.

[3] Zhang Z, Li W, Li J, Chao YJ. Numerical analysis of effect of backplate diffusivity on the transient temperature in friction stir welding. Journal of Materials Engineering and Performance. 2013;22(9):2446-2450. http://dx.doi.org/10.1007/s11665-013-0538-7.

[4] De Backer J, Bolmsjö G, Christiansson A-K. Temperature control of robotic friction stir welding using the thermoelectric effect. International Journal of Advanced Manufacturing Technology. 2014;70(1-4):375-383. http://dx.doi.org/10.1007/s00170-013-5279-0.

[5] De Backer J, Bolmsjo G. Thermoelectric method for temperature measurement in friction stir welding. Science and Technology of Welding and Joining. 2013;18(7):558. http://dx.doi.org/10.1179/1362171813Y.0000000135.

[6] Fehrenbacher A, Schmale JR, Zinn MR, Pfefferkorn FE. Measurement of tool-workpiece interface temperature distribution in friction stir welding. Journal of Manufacturing Science and Engineering. 2014;136(2):021009-021009. http://dx.doi.org/10.1115/1.4026115. 
[7] Schmale J, Fehrenbacher A, Shrivastava A, Pfefferkorn FE. Calibration of dynamic tool-workpiece interface temperature measurement during friction stir welding. Measurement. 2016;88:331-342. http://dx.doi.org/10.1016/j.measurement.2016.02.065.

[8] Ross K. Temperature control in friction stir welding for industrial and research applications. In: Proceedings of the 10th International Symposium on Friction Stir Welding; 2014; Beijing, China. Cambridge: TWI; 2014.

[9] Ross KA. Investigation and implementation of a robust temperature control algorithm for friction stir welding [thesis]. Provo: Department of Mechanical Engineering, Brigham Young University; 2012.

[10] Fehrenbacher A, Smith CB, Duffie NA, Ferrier NJ, Pfefferkorn FE, Zinn MR. Combined temperature and force control for robotic friction stir welding. Journal of Manufacturing Science and Engineering. 2014;136(2):136. http://dx.doi.org/10.1115/1.4025912.

[11] Cederqvist L. Friction stir welding of copper canisters using power and temperature control [thesis]. Lund: Department of Design Sciences, Lund University; 2011.

[12] Cederqvist L, Garpinger O, Hägglund T, Robertsson A. Cascade control of the friction stir welding process to seal canisters for spent nuclear fuel. Control Engineering Practice. 2012;20(1):35-48. http://dx.doi.org/10.1016/j.conengprac.2011.08.009.

[13] De Backer J. Feedback control of robotic friction stir welding [thesis]. Sweden: University West; 2014. p. 134.

[14] Silva ACF, De Backer J, Bolmsjö G. Temperature measurements during friction stir welding. International Journal of Advanced Manufacturing Technology. 2017;88(9-12):2899-2908. http://dx.doi.org/10.1007/s00170-016-9007-4.

[15] Silva ACF, Braga DFO, Figueiredo MAV, Moreira PMGP. Ultimate tensile strength optimization of different FSW aluminium alloy joints. International Journal of Advanced Manufacturing Technology. 2015;79(5-8):805. http://dx.doi.org/10.1007/s00170-015-6871-2.

[16] Silva ACF, Backer JD, Bolmsjö G. Analysis of plunge and dwell parameters of robotic FSW using TWT temperature feedback control. In: Proceedings of the 11th International Symposium on Friction Stir Welding (11ISFSW); 2016; Cambridge. Cambridge: TWI; 2016.

[17] Silva ACF, De Backer J, Bolmsjö G. TWT method for temperature measurement during FSW process. In: Proceedings of the FSWP 2015 International Conference; 2015; Ordizia, Spain. Spain: FSWP; 2015. p. 95-98.

[18] Magalhães A. Thermo-electric temperature measurements in friction stir welding: towards feedback control of temperature [thesis]. Sweden: Department of Engineering Science, University West; 2016.

[19] Hamilton C, Kopyściański M, Senkov O, Dymek S. A coupled thermal/material flow model of friction stir welding applied to sc-modified aluminum alloys. Metallurgical and Materials Transactions A: Physical Metallurgy and Materials Science. 2013;44(4):1730-1740. http://dx.doi.org/10.1007/s11661-012-1512-y.

[20] American Society for Testing and Materials. ASTM E8/E8M-09: standard test methods for tension testing of metallic materials. West Conshohocken: ASTM; 2009. 